\title{
Interaction between potyvirus and crinivirus in sweet potato ${ }^{1}$
}

\author{
Sofía Solange Flamarique ${ }^{2}$, Antonella Vilanova Perez ${ }^{3}$, \\ Andrea Peña Malavera ${ }^{4}$, Julia Martino ${ }^{5}$, Liliana Di Feo ${ }^{3}$
}

\section{ABSTRACT}

Sweet potato, in Argentina, is affected by the "encrespamiento amarillo", a viral disease in which seven viruses are involved, among them two potyvirus (sweet potato feathery mottle virus - SPFMV and sweet potato virus G - SPVG) and a crinivirus (sweet potato chlorotic stunt virus - SPCSV). This research aimed to study the interaction between SPFMV and SPVG with SPCSV in sweet potato. Two sweet potato cultivars (Gem and Arapey INIA) and Ipomoea setosa as an indicator susceptible plant were tested as single (SPFMV or SPVG), double (SPFMV + SPVG, SPFMV + SPCSV or SPVG + SPCSV) or triple (SPFMV + SPVG + SPCSV) grafts. Both potyviruses were purified and the viral concentrations in the plant tissues were quantified by the DAS-Elisa method. The viruses and their severities were evaluated at 7, 15, 21, 30 and 35 days post-inoculation. A synergistic effect was observed with the three viruses in the indicator plant. The viral concentration increase was 50 times for SPFMV (day 35) and two times for SPVG (day 21) in the Gem cultivar, and 1.89 times for SPFMV (day 35) and three times for SPVG (day 7) in the Arapey INIA. For multiple infections, the indicator plant and the Gem cultivar exhibited synergistic symptoms and increase in the viral titers, with a higher severity and variability of the symptoms. Co-infections such as SPFMV + SPVG showed characteristic potyvirus symptoms, without increasing the viral concentrations; triple co-infections exhibited viral complex symptoms, with increase in the potyvirus titers; and the symptoms were mild or imperceptible in the simple infections.

KEYWORDS: Ipomoea batatas, SPFMV, SPVG, SPCSV, virus concentration.

\section{INTRODUCTION}

Sweet potato [Ipomoea batatas (L.) Lam.] is a member of the Convolvulaceae family, with origin in

\section{RESUMO}

Interação entre potyvírus e crinivírus em batata-doce

$\mathrm{Na}$ Argentina, a batata-doce é afetada pelo "encrespamiento amarillo", uma virose causada por um complexo de sete vírus, dentre eles dois potyvírus (sweet potato feathery mottle virus - SPFMV e sweet potato virus G - SPVG) e um crinivírus (sweet potato chlorotic stunt virus - SPCSV). Objetivou-se estudar a interação entre SPFMV e SPVG com SPCSV em batata-doce. Duas cultivares de batata-doce (Gem e Arapey INIA) e Ipomoea setosa como planta indicadora sucetível foram testadas como enxertos único (SPFMV ou SPVG), duplo (SPFMV + SPVG, SPFMV + SPCSV ou SPVG + SPCSV) ou triplo (SPFMV + SPVG + SPCSV). Ambos os potyvírus foram purificados e as concentrações virais nos tecidos das plantas foram quantificadas pelo método DAS-Elisa. Os vírus e suas severidades foram avaliados aos 7, 15, 21, 30 e 35 dias após a inoculação. Observou-se efeito sinérgico com os três vírus na planta indicadora. O aumento da concentração viral foi de 50 vezes para SPFMV (dia 35) e duas vezes para SPVG (dia 21) na cultivar Gem e de 1,89 vezes para SPFMV (dia 35) e três vezes para SPVG (dia 7) na Arapey INIA. Em múltiplas infecções, a planta indicadora e a cultivar Gem exibiram sintomas de sinergia e aumento nos títulos virais, com maior severidade e variabilidade dos sintomas. Coinfecções como SPFMV+ SPVG mostraram sintomas característicos de potyvírus, sem aumentar as concentrações virais; coinfecções triplas apresentaram sintomas do complexo viral, com aumento nos títulos dos potyvírus; e os sintomas foram leves ou imperceptíveis nas infecções simples.

KEYWORDS: Ipomoea batatas, SPFMV, SPVG, SPCSV, virus concentration.

northwestern South America. Its cultivation is carried out in more than one hundred countries of tropical, subtropical and temperate regions (Clark et al. 2012, Lan et al. 2018). Its production is concentrated in

1. Received: May 27, 2019. Accepted: Oct. 15, 2019. Published: Mar. 10, 2020. DOI: 10.1590/1983-40632020v5058735.

2. Universidad Nacional de Córdoba, Facultad de Ciencias Exactas, Físicas y Naturales, Córdoba, Argentina.

Email/ORCID: soflamarique@gmail.com/0000-0002-4298-5747.

3. Instituto de Patología Vegetal, Centro de Investigaciones Agropecuarias, Instituto Nacional de Tecnología Agropecuaria, Córdoba, Argentina. Email/ORCID: vilanova.antonella@inta.gob.ar/0000-0001-7887-9092, difeo.liliana@inta.gob.ar/0000-0001-6480-2107.

4. Instituto de Tecnología Agroindustrial del Noroeste Argentino, Estación Experimental Agroindustrial Obispo Colombres,

Consejo Nacional de Investigaciones Científicas y Técnicas, Tucumán, Argentina.Email/ORCID: andreapema@gmail.com/ 0000-0002-5757-8722.

5. Consejo Nacional de Investigaciones Científicas y Técnicas, Córdoba, Argentina. Email/ORCID: martino.julia@inta.gob.ar/0000-0002-9024-6340. 
China ( $80 \%$ of the world's total) and around the Great Lakes of east Africa (Clark et al. 2012).

In Argentina, the Pampa (provinces of Buenos Aires, Córdoba and Santa Fe) and northeastern regions are the largest planted areas $(43 \%$ and $40 \%$, respectively). The northwest region produces $15 \%$, and the remaining $2 \%$ correspond to Cuyo - Mendoza and San Juan (Rodríguez Pardina et al. 2012). However, the surface with sweet potato in Argentina, in 2018, was 22.772 ha, compared to 32.100 ha, in 1986 (FAO 2019). This is because all the sweet potato cultivars are commercially propagated in an agamic way, leading to the accumulation of viruses that reduce their production (Lozano et al. 2009).

All regions of sweet potato cultivation in Argentina are affected by a serious disease called "encrespamiento Amarillo" (EA). This disease affects not only the commonly planted variety, Arapey INIA, but also those used in the different regions, causing significant losses in the production (more than $90 \%$ in number and weight of reserve roots), in experimental trials and in commercial lots (López Colomba et al. 2011). According to these authors, virus infections also affect the quality of the storage roots and contribute to the reduction of $\beta$-carotenes.

EA is caused by seven viruses (Pardina et al. 2012, Rodriguez Pardina et al. 2012, Bejerman et al. 2016, Martino et al. 2016, Martino et al. 2017). Among these, two are members of the Potyvirus genus [nonpersistently transmitted by Myzus persicae, sweet potato fathery mottle virus - SPFMV (Bejerman et al. 2016) and sweet potato virus G - SPVG (Pardina et al. 2012)] and one crinivirus [semipersistently transmitted by Bemisia tabaci, called sweet potato chlorotic sunt virus - SPCSV (Di Feo et al. 2000)].

SPFMV is the most widespread sweet potato infecting virus worldwide and, with SPCSV, produces the sweet potato virus disease (SPVD). This is the most relevant viral disease for this crop, because it causes up to $90 \%$ of yield losses (Karyeija et al. 1998, Li et al. 2012, Adikini et al. 2016, Nhlapo et al. 2018).

In single infections, each one of these viruses does not manifest phenotypically, or it only causes mild symptomatology (low severity) such as chlorotic spots on the older leaves (SPFMV) (Untiveros et al. 2007, Adikini et al. 2016, Nhlapo et al. 2018). In co-infections, there is a synergistic interaction with an increase in the virus concentration, replication and movement of SPFMV. This leads to a noticeable severity of symptoms (stunting, chlorosis, distortion and decrease of foliar area) and yield losses (Gutiérrez et al. 2003, Untiveros et al. 2007, Syller 2012). However, there are studies establishing that SPVG is able to induce SPVD in mixed infections with SPCSV (Kokkinos \& Clark 2006, Li et al. 2012). In addition, a previous study about the relationship between both the potyvirus (SPFMV and SPVG) concluded on the existence of a possible antagonism between both viruses, according to which SPVG exhibits a decrease in its concentration in co-infection with SPFMV (Martinelli 2014).

This study aimed to assess the interaction between SPFMV and SPVG in double and triple infections with SPCSV, in order to determine the symptomatology and disease severity in sweet potato cultivars, also compared with an indicator susceptible plant of the same genus.

\section{MATERIAL AND METHODS}

The experiments were conducted at the Instituto de Patología Vegetal (IPAVE) - Centro de Investigaciones Agropecuarias of the Instituto Nacional de Tecnología Agropecuaria (CIAP-INTA Córdoba, Argentina), from January 2017 to May 2018.

SPFMV was separated from SPVG on Ipomoea setosa, an indicator susceptible plant, by M. persicae aphids, in one probe test. The sources of inoculum were sweet potato plants (cv. Arapey INIA) infected with the disease (Kennedy \& Moyer 1982, Di Feo et al. 2000). On the other hand, SPCSV was isolated by $B$. tabaci transmission. I. setosa plants were tested by double-antibody sandwich enzyme-linked immunosorbent assay (DASELISA) and immunosorbent electron microscopy and decoration (ISEM-D) against SPFMV and SPVG antisera, respectively (Clark \& Adams 1977, Gibson et al. 1998). SPCSV single infections were confirmed by triple-antibody sandwich enzymelinked immunosorbent assay - TAS-ELISA (Gibson et al. 1998).

The Arapey INIA and Gem cultivars (healthy plants obtained by in vitro culture of meristems) and I. setosa indicator plants were inoculated by side grafting. The treatments were: single grafts (with SPFMV or SPVG, respectively); double grafts (SPFMV + SPVG, SPFMV + SPCSV or 
SPVG + SPCSV) and triple grafts (SPFMV + SPVG + SPCSV). Finally, healthy plants were mockinoculated using side grafting. The plants were kept in protected cages with anti-aphid mesh at $25^{\circ} \mathrm{C}$, in a greenhouse, in controlled conditions of humidity and photoperiod. Symptoms were recorded at 7, 15, 21, 30 and 35 days post-inoculation (DPI). A four-degree $a d$ hoc symptom scale was established with the following grades: 0 - asymptomatic plant; 1 - chlorotic spots on basal leaves and normal size; 2 - mild chlorosis, mosaic and size lower than normal; 3 - notable chlorosis and growth reduction, mosaic, decreased leaf area and severe distortion in the leaf shape.

The SPFMV and SPVG concentrations were determined at 7, 15, 21, 30 and 35 DPI by DASELISA (Clark \& Adams 1977). Polyclonal antisera from IPAVE (1:1000 dilution) were used for both, and IgG and enzymatic conjugate for SPFMV. For SPVG, the $\operatorname{IgG}$ and enzymatic conjugate dilutions were 1:1000 and 1:500, respectively, as done in previous calibration tests. Symptomatic leaves or leaves from the upper part of the the sweet potato cultivars and indicator plant were selected and used.

Previously, both potyviruses were purified according to Di Feo et al. (2000). For the construction of the pattern curve of viral concentration by DASELISA, serial dilutions of viruses were made in pure vegetable juice (from healthy $I$. setosa) and in 1X PBS buffer, containing Tween $20(0.05 \%)$, PVP (2 \%), BSA (2\%) and $\mathrm{SO}_{3} \mathrm{Na}_{2}(0.2 \%)$. These dilutions were: $1 / 2,1 / 3,1 / 4,1 / 5,1 / 8,1 / 9,1 / 10,1 / 16$, $1 / 20,1 / 27,1 / 32,1 / 40,1 / 64,1 / 80,1 / 81,1 / 128,1 / 160$, $1 / 243,1 / 256,1 / 320,1 / 512,1 / 640,1 / 1024,1 / 1280$, $1 / 2048,1 / 2187,1 / 2560,1 / 4096,1 / 5120$ and $1 / 6561$. The absorbance at $\lambda=405\left(\mathrm{~A}_{405}\right)$ was recorded in an ELISA plate reader (Labsystems Multiskan MS) at 90 min from the addition of the substrate.

To adjust the pattern curve of viral concentration in plant tissues, a non-linear regression analysis was used, setting a Gompertz model for SPFMV and a logistic model for SPVG. As a dependent variable, the known viral concentration was taken, and, as a regressive variable, the absorbance at $90 \mathrm{~min}$. A general linear model analysis was performed with Varldent $\mathrm{g}(\mathrm{d})=\mathrm{d}$ function for the treatment factor, in order to evaluate differences of concentration between the treatments for each day and each variety. The analyses were performed at $5 \%$ of significance, using the InfoStat statistical software (Di Rienzo et al. 2017).

\section{RESULTS AND DISCUSSION}

In single infections, the first symptoms on the indicator plant (I. setosa) appeared at 15 DPI (feathery mottling and vein clearing on the older leaves) and 21 DPI [mosaic and chlorotic spots with remission of symptoms at 35 DPI (Untiveros et al. 2007, Adikini et al. 2016)] (Figures 1B and 1C). The Arapey INIA cultivar showed feathery mottle at 30 DPI (Figure 3B), while Gem showed vein clearing and hyponasty (leaf border curved downward) at 35 DPI (Figures 2B and 2C).

SPVG caused vein clearing at $15 \mathrm{DPI}$, and chlorotic spots and mosaic at 21 DPI, in upper and lower leaves from I. setosa and the two sweet potato cultivars (Figures 2D, 3C and 3D). In opposition, Martinelli (2014) did not observe symptomatology in Arapey INIA. According to this study, the indicator plant exhibited blistering, vein clearing and mosaic, mainly in lower leaves, and, in a lesser degree, in upper leaves (Figures 1D and 1E).

In single infections, SPFMV only causes mild symptoms, or these do not manifest phenotypically; while, in mixed infections with SPCSV, generalized severe symptoms (stunting, chlorosis, distortion and decreased leaf area) and yield losses occur (Di Feo et al. 2000, Gutiérrez et al. 2003, Kreuze et al. 2009, Adikini et al. 2016). In this study, SPCSV + SPFMV in I. setosa (Figures $1 \mathrm{~F}$ and $1 \mathrm{G}$ ) and Gem (Figures $2 \mathrm{E}, 2 \mathrm{~F}$ and $2 \mathrm{G}$ ) produced mosaic, feathery mottle, chlorotic spots, reduction and distortion of leaf area, vein banding and blisters at 21 DPI; while Arapey INIA showed no symptoms (Untiveros et al. 2007). However, SPVG is able to induce typical symptoms of a viral complex in co-infection with SPCSV (Kokkinos \& Clark 2006, Li et al. 2012). According to Martinelli (2014), Arapey INIA also showed vein clearing and, then, a slight distortion and severe mosaic.

In this study, besides the Martinelli's symptoms, feathery mottle and chlorotic spots were observed in I. setosa (Figures 1H and 1I) and Arapey INIA(Figure 3E); while Gem presented vein clearing (Figure 2H). All this symptoms were noticed at 21 DPI. Moreover, the three genotypes showed shoelace (deformation and progressive leaf area reduction towards the distal portion of the guides) at $30 \mathrm{DPI}$ (Figures 4A, 4B and 4E).

Untiveros et al. (2007) noticed that the plants remained asymptomatic, without any evidence of 

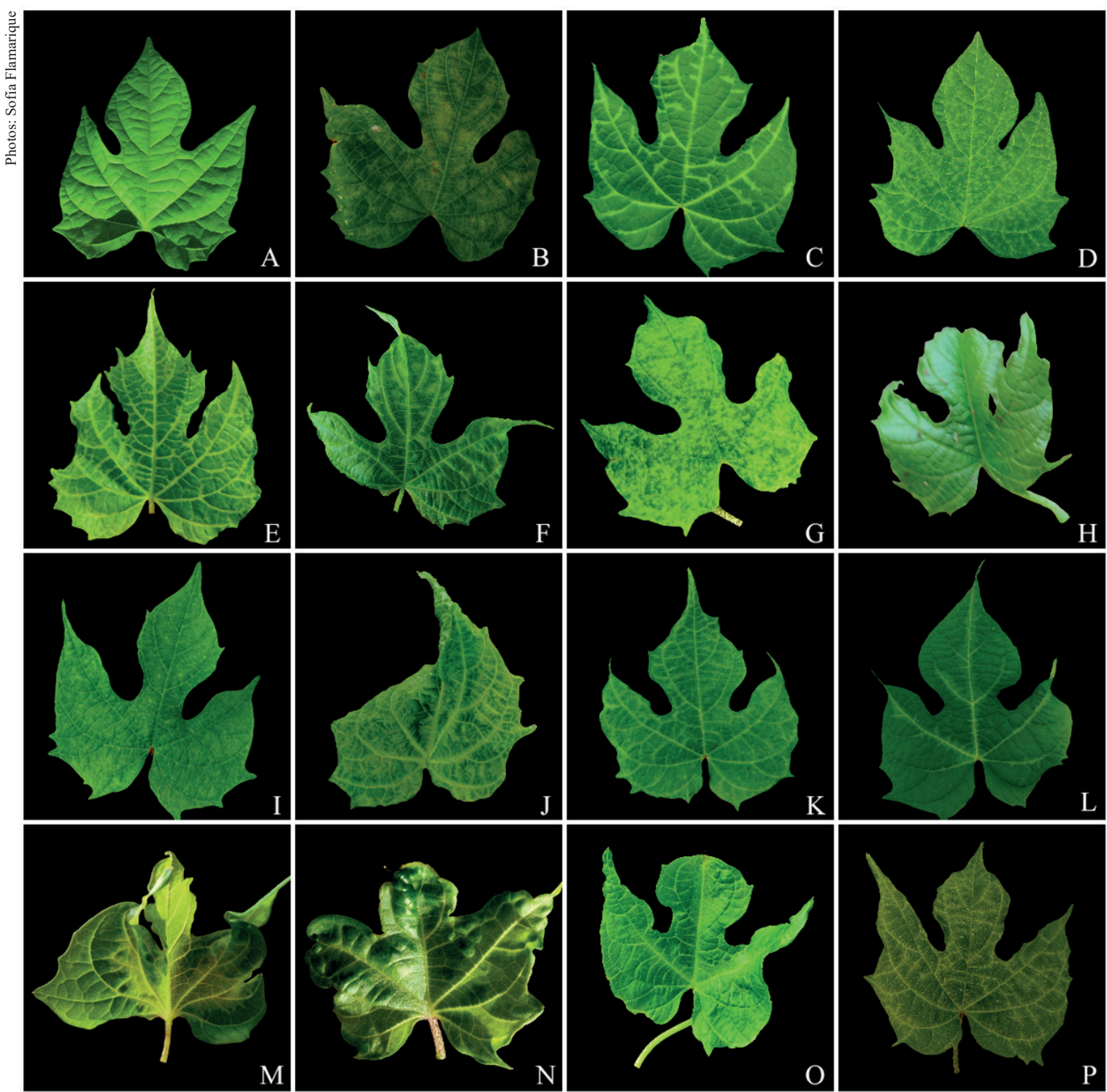

Figure 1. Foliar symptoms on the indicator plant Ipomoea setosa infected with the viruses SPFMV, SPVG and SPCSV, in different combinations: healthy leaf(A), mosaic (B) and feathery mottle (C) caused by SPFMV; chlorotic spots (D) and vein clearing (E) caused by SPVG; vein banding, mosaic, blisters, distortion plus decreased leaf area (F) and mosaic $(\mathrm{G})$ caused by SPFMV + SPCSV; decreased leaf area $(\mathrm{H})$ and mosaic plus chlorotic spots (I) caused by SPVG + SPCSV; distortion of leaf shape, mosaic, feathery mottle and vein clearing $(\mathrm{J})$, feathery mottle, vein banding and chlorotic spots $(\mathrm{K})$ and feathery mottle (L) caused by SPFMV + SPVG; distortion and decreased leaf area (M), feathery mottle and blisters $(\mathrm{N})$, feathery mottle $(\mathrm{O})$ and mosaic plus feathery mottle $(\mathrm{P})$ caused by SPFMV + SPVG + SPCSV.

synergy among the pathogens, when they were grafted with SPFMV and another potyvirus, such as sweet potato latent virus (SPLV) or sweet potato mild speckling virus (SPMSV). In contrast, in this study, infections with SPFMV and SPVG, at 15 DPI, increased to typical symptoms of potyvirus, such as chlorotic spots, feathery mottle in the main veins, vein clearing and vein banding in lower leaves for Gem and I. setosa plants (Figures 1J, 1K, 1L, 2I, 2J and $2 \mathrm{~K}$ ); but Arapey INIA only showed chlorotic spots at 21 DPI (Figure 3F).

Multiple infections (SPFMV + SPVG + SPCSV) induced severe symptomatology at 7 DPI in I. setosa: feathery mottle, mosaic, vein clearing, leaf deformation and shoe-lace (Figures 1M, 1N, $1 \mathrm{O}$ and 1P). Arapey INIA plants exhibited chlorotic spots in upper and lower leaves and, to a lesser degree, vein clearing and feathery mottle (Figures $3 \mathrm{G}, 3 \mathrm{H}$ and $3 \mathrm{I}$ ); 

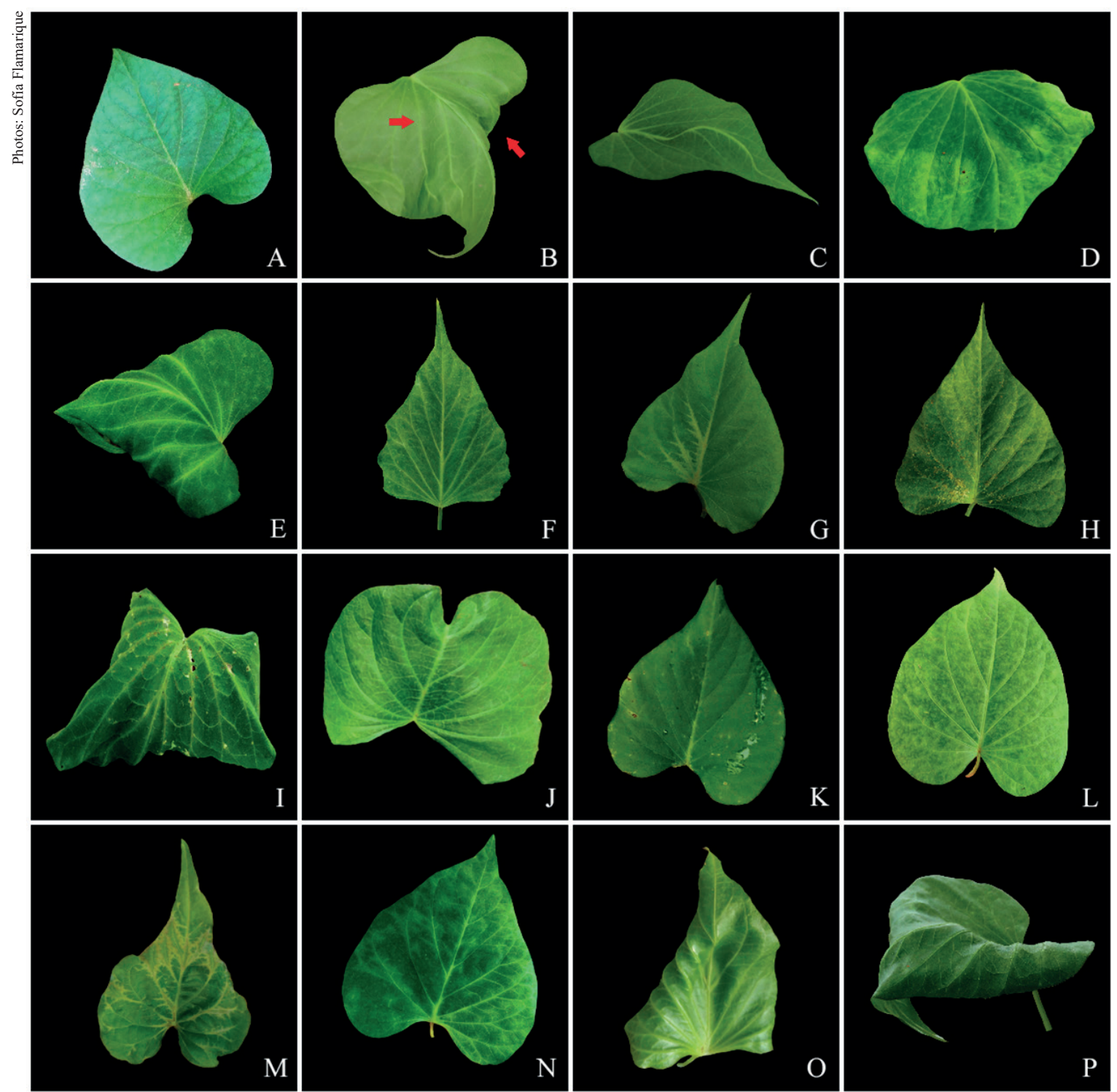

Figure 2. Foliar symptoms on Gem sweet potato infected with the viruses SPFMV, SPVG and SPCSV, in different combinations: healthy leaf (A), distortion of leaf shape, thickened central vein, vein banding, vein clearing plus hyponasty (B) and thickened central vein, distortion of leaf shape plus vein clearing (C) caused by SPFMV; feathery mottle and hyponasty (D) caused by SPVG; vein thickening, vein banding, chlorotic spots and hyponasty (E), vein clearing (F) and feathery mottle $(G)$ caused by SPFMV + SPCSV; vein clearing and mosaic $(H)$ caused by SPVG + SPCSV; vein clearing, vein thickening and hyponasty (I), hyponasty plus vein clearing $(\mathrm{J})$ and chlorotic spots $(\mathrm{K})$ caused by SPFMV + SPVG; vein clearing and chlorotic spots $(\mathrm{L})$, feathery mottle and distortion of leaf shape $(\mathrm{M})$, mosaic $(\mathrm{N})$, distortion of leaf shape plus vein thickening $(\mathrm{O})$ and vein thickening and hyponasty $(\mathrm{P})$ caused by SPFMV + SPVG + SPCSV.

while Gem plants manifested feathery mottle, leaf deformation and vein thickening. At 30 and 35 DPI, they showed chlorotic spots, mosaic and vein clearing (Figures 2L, 2M, 2N, $2 \mathrm{O}$ and 2P). The symptoms induced by SPFMV + SPVG + SPCSV co-infection were severe, similarly to those caused by sweet potato chlorotic dwarf (SPCD), a disease that affected sweet potato in Argentina, in the 1990s (Di Feo et al. 2000). It was caused by the interaction between two potyvirus (SPFMV and SPMSV) and SPCSV, and produced severe mosaic, chlorosis, stunting and shoe-lace (Di Feo et al. 2000, Untiveros et al. 2007).

The concentration of SPFMV and SPVG in the plant tissue juice, expressed in $\mathrm{mg} \mathrm{mL}^{-1}$, was calculated by different fitted equations (Figures $5 \mathrm{~A}$ and $5 \mathrm{~B})$. 


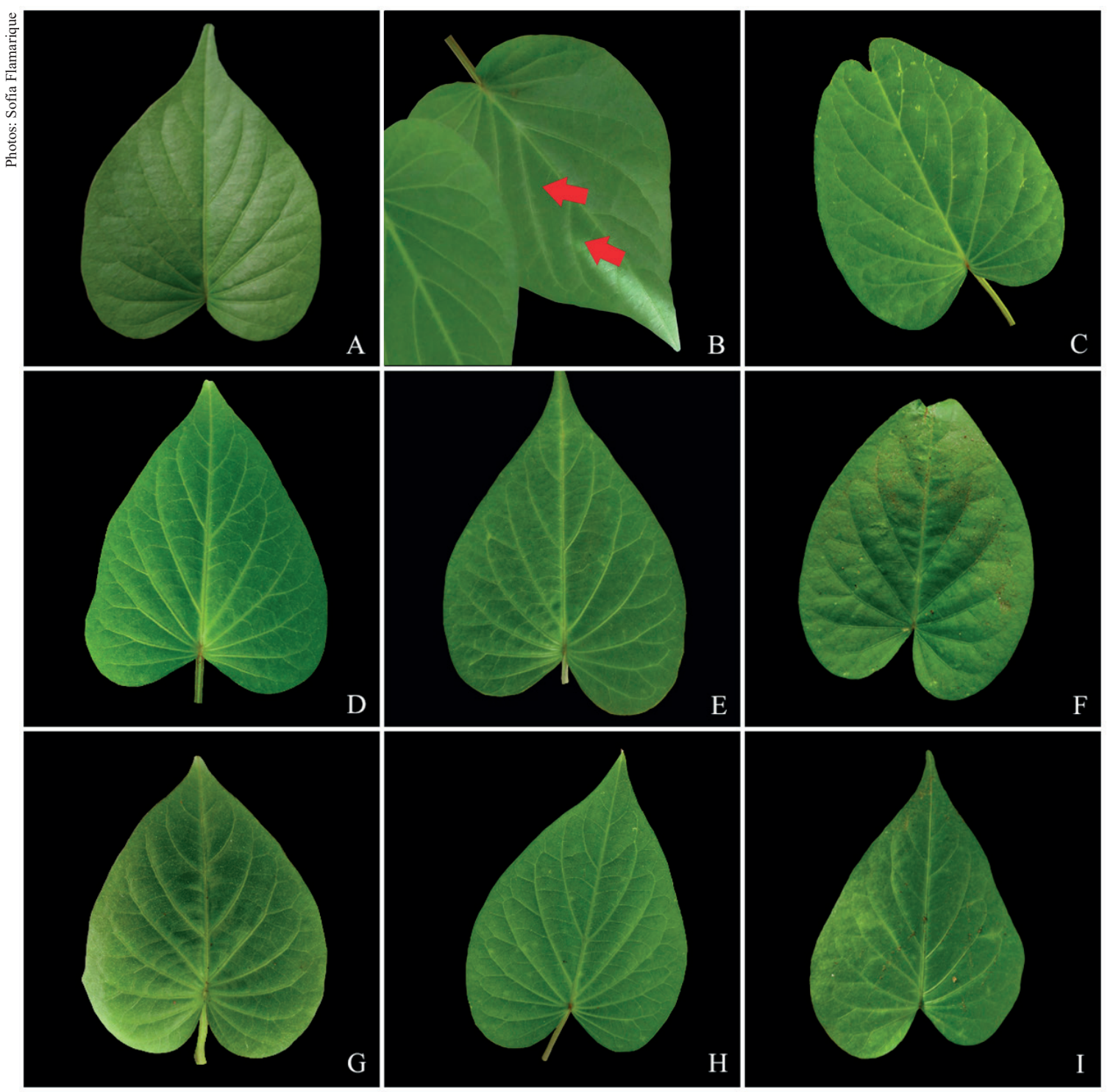

Figure 3. Foliar symptoms for Arapey INIA sweet potato infected with the viruses SPFMV, SPVG and SPCSV, in different combinations: healthy leaf (A) and feathery mottle (B) caused by SPFMV; chlorotic spots (C) and vein clearing (D) caused by SPVG; vein clearing and chlorotic spots (E) caused by SPVG + SPCSV; chlorotic spots (F) caused by SPFMV + SPVG; vein clearing $(\mathrm{G})$, chlorotic spots $(\mathrm{H})$ and feathery mottle (I) caused by SPFMV + SPVG + SPCSV.

There was evidence of synergistic interaction in multiple infections (SPFMV + SPVG + SPCSV), with significant increases in titers, especially in I. setosa, in relation to single infections of SPFMV or SPVG. These increments in this indicator plant were 152 times at 7 DPI for SPFMV and 121 times at 15 DPI for SPVG (Figure 6A). In Gem, the viral concentration increased 53 times at 35 DPI for SPFMV and twice at 21 DPI for SPVG (Figure 6B). The symptomatology expression was also severe for both the indicator plant and the sweet potato cultivar. In Arapey INIA, despite the 1.89 times increase in the concentration for SPFMV at 35 DPI and three times for SPVG at 7 DPI, plants only showed mild symptoms (Figure 6C).

Increases in viral titers suggest that the expression of the symptoms or an increase in their severity may occur due to an increment in the levels of virus accumulation in plant tissues (Untiveros et al. 2007). The highest concentrations of viruses occurred firstly in I. setosa, secondly in the Gem cultivar, and after in the Arapey INIA cultivar. In addition, the sweet potato cultivars showed different behaviors for double (SPFMV + SPVG) or triple (SPFMV + 


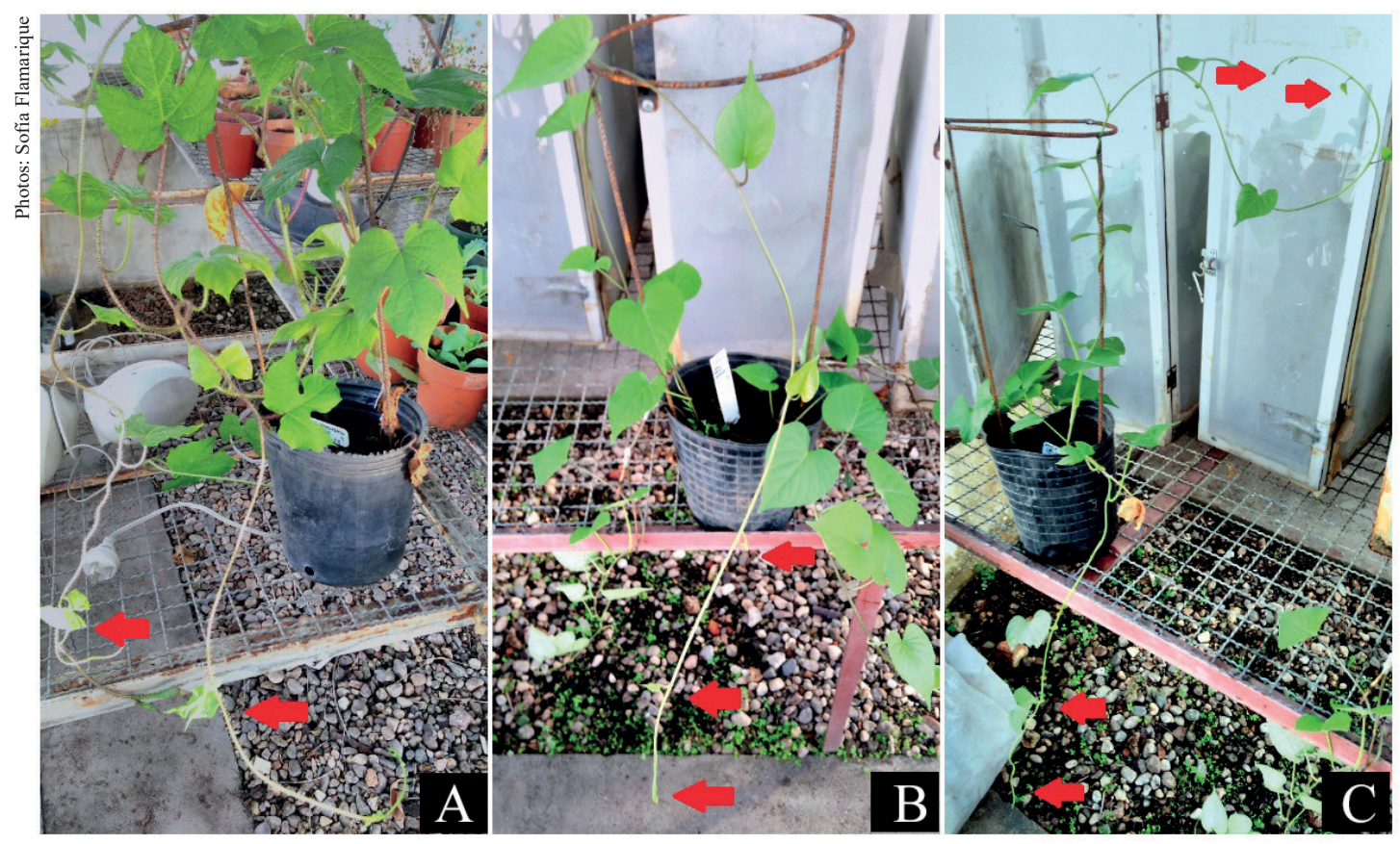

Figure 4. Shoe-lace (deformation and progressive leaf area reduction towards the distal portion of the guides) on the Ipomoea setosa (A) indicator plant and on the Arapey INIA (B) and Gem (C) sweet potato cultivars infected with a combination of viruses SPVG + SPCSV.
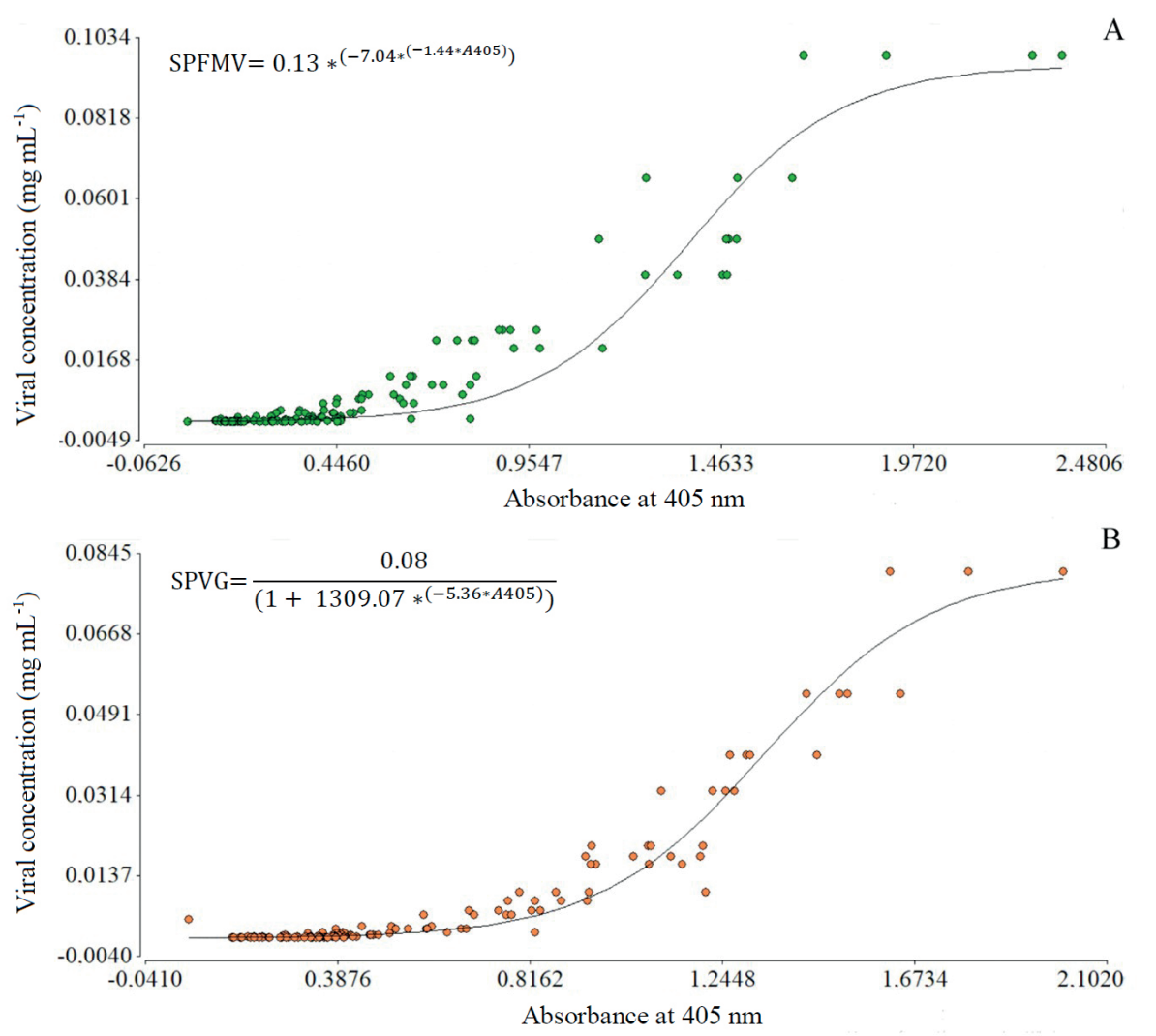

Figure 5. Pattern curves of viral concentration in plant tissues for sweet potato feathery mottle virus (SPFMV) and sweet potato virus $\mathrm{G}$ (SPVG), as a function of the absorbance at $90 \mathrm{~min}($ A405). A Gompertz model was fitted for A $(\mathrm{p}<0.001)$ and a logistic model for B $(\mathrm{p}<0.001)$. 

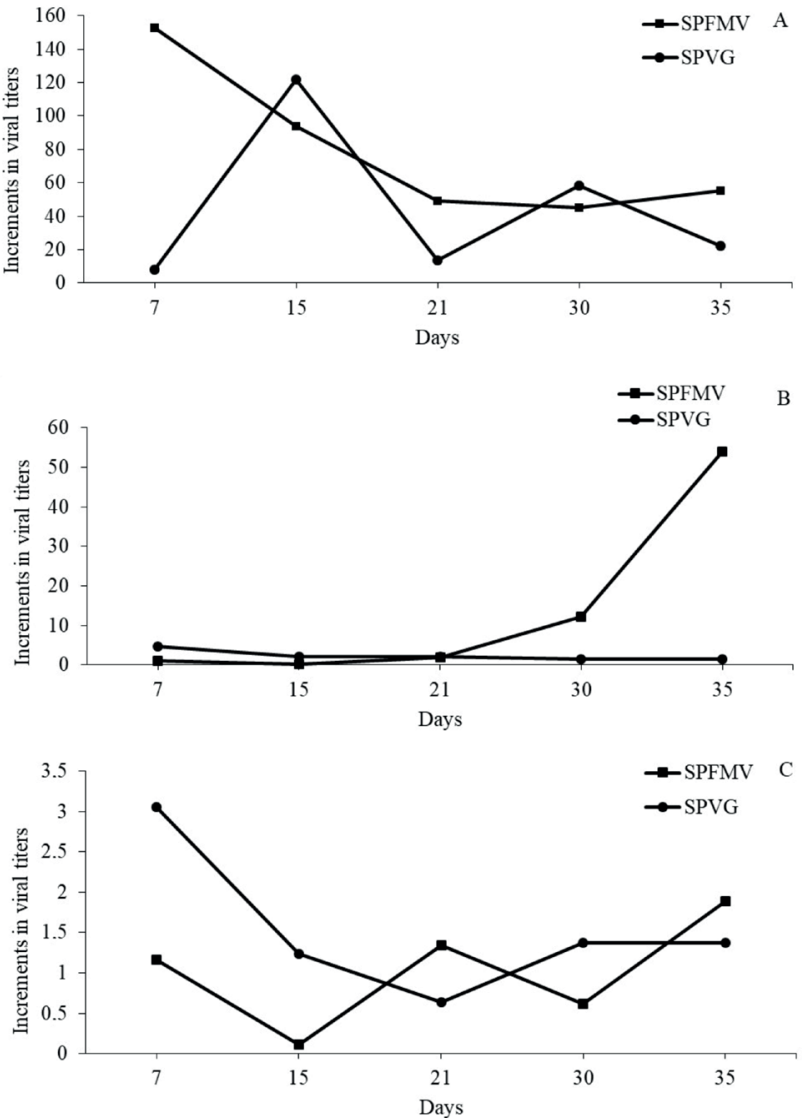

Figure 6. Increments in viral titers on the Ipomoea setosa (A) indicator plant and the Gem (B) and Arapey INIA (C) sweet potato cultivars, from 7 to 35 days postinoculation by sweet potato feathery mottle virus (SPFMV) and sweet potato virus G (SPVG).

SPVG + SPCSV) potyvirus infections, with more severe symptomatology for the triple one. Finally, it was found that viral concentrations of each potyvirus were similar in co-infection (SPFMV + SPVG) and single grafting.

\section{CONCLUSIONS}

1. The Gem and Arapey INIA sweet potato (Ipomoea batatas) cultivars exhibit a differential behavior against viral infections;

2. In single viral infections, the symptomatology for Gem (I. batatas) and for the susceptible indicator plant (Ipomoea setosa) is mild;

3. The multiple viral infection with potyviruses and crinivirus (SPFMV + SPVG + SPCSV) induces a greater severity of symptoms, especially for Gem (I. batatas) and for the susceptible indicator
(I. setosa); plants on which there is also a synergistic effect from this infection;

4. In the SPFMV + SPVG co-infection, the symptoms are characteristic of a potyvirus disease; but, in those with crinivirus (SPFMV + SPCSV or SPVG + SPCSV), the plants express severe symptoms of the viral complex.

\section{ACKNOWLEDGMENTS}

To the Instituto de Patología Vegetal (IPAVE) Centro de Investigaciones Agropecuarias of the Instituto Nacional de Tecnología Agropecuaria (CIAP-INTA Córdoba), for allowing this research to be carried out at its headquarters.

\section{REFERENCES}

ADIKINI, S.; MUKASA, S. B.; MWANGA, R. O. M.; GIBSON, R. W. Effects of sweet potato feathery mottle virus and sweet potato chlorotic stunt virus on the yield of sweet potato in Uganda. Journal of Phytopathology, v. 164, n. 4, p. 242-254, 2016.

BEJERMAN, N.; ZANINI, A.; RODRIGUEZ PARDINA, P.; DI FEO, L. Use of 454-pyrosequencing for the characterization of sweet potato virus $\mathrm{C}$ and sweet potato feathery mottle virus isolates from Argentina and development of a multiplex one-step RT-PCR for their simultaneous detection. Journal of Phytopathology, v. 164, n. 6, p. 386-394, 2016.

CLARK, C. A.; DAVIS, J. A.; ABAD, J. A.; CUELLAR, W. J.; FUENTES, S.; KREUZE, J. F.; GIBSON, R. W.; MUKASA, S. B.; TUGUME, A. K.; TAIRO, F. D. Sweet potato viruses: 15 years of progress on understanding and managing complex diseases. Plant Disease, v. 96, n. 2, p. $168-185,2012$.

CLARK, M. F.; ADAMS, A. N. Characteristics of the microplate method of enzyme-linked immunosorbent assay for the detection of plant viruses. Journal of General Virology, v. 34, n. 3, p. 475-483, 1977.

DI FEO, L.; NOME, S. F.; BIDERBOST, E.; FUENTES, S.; SALAZAR, L. F. Etiology of sweet potato chlorotic dwarf disease in Argentina. Plant Disease, v. 84, n. 1, p. 35-39, 2000.

DI RIENZO, J. A.; CASANOVES, F.; BALZARINO, M. G.; GONZALEZ, L.; TABLADA, M.; ROBLEDO, C. W. Infostat. 2017. Available at: http://www.infostat.com.ar. Access on: 17 May 2018.

FOOD AND AGRICULTURE ORGANIZATION OF THE UNITED NATIONS (FAO). Faostat. 2019. Available 
at: http://www.fao.org/faostat/es/\#data/QC. Access on: 24 Feb. 2020.

GIBSON, R. W.; MPEMBE, I.; ALICAI, T.; CAREY, E.; MWANGA, R. O. M.; SEAL, S. E.; VETTEN, J. Symptoms, a etiology and serological analysis of sweet potato virus disease in Uganda. Plant Pathology, v. 47, n. 1, p. 95-102, 1998.

GUTIÉRREZ, D.; FUENTES, S.; SALAZAR, L. Sweet potato virus disease (SPVD): distribution, incidence and effect on sweet potato yield in Peru. Plant Disease, v. 87, n. 3, p. 297-302, 2003.

KARYEIJA, R. F.; GIBSON, R. W.; VALKONEN, J. P. T. Resistance to sweet potato virus disease (SPVD) in wild East African Ipomoea. Annals of Applied Biology, v. 133, n. 1, p. 39-44, 1998.

KENNEDY, G. G.; MOYER, J. M. Aphid transmission and separation of two strains of sweet potato feathery mottle virus from sweet potato. Journal of Economic Entomology, v. 75 , n. 1 , p. $130-133,1982$.

KOKKINOS, C. D.; CLARK, C. A. Interactions among sweet potato chlorotic stunt virus and different potyvirus and potyvirus strains infecting sweet potato in the United States. Plant Disease, v. 90, n. 10, p. 13471352, 2006.

KREUZE, J. F.; PEREZ, A.; UNTIVEROS, M.; QUISPE, S.; FUENTES, S.; BARKER, I.; SIMON, R. Complete viral genome sequence and discovery of novel viruses by deep sequencing of small RNAs: a generic method for diagnosis, discovery and sequencing of viruses. Virology, v. 388, n. 1, p. 1-7, 2009.

LAN, P.; LI, F.; ABAD, J.; PU, L.; LI, R. Simultaneous detection and differentiation of three potyviridae viruses in sweet potato by a multiplex TaqMan real time RT-PCR assay. Journal of Virological Methods, v. 252, n. 1, p. 2431, 2018.

LI, F.; XU, D.; ABAD, J.; LI, R. Phylogenetic relationships of closely related potyviruses infecting sweet potato determined by genomic characterization of sweet potato virus $\mathrm{G}$ and sweet potato virus 2. Virus Genes, v. $45, \mathrm{n} .1$, p. 118-125, 2012.

LÓPEZ COLOMBA, E.; RODRÍGUEZ PARDINA, P.; LUQUE, A.; NOME, C.; NOME, F.; DI FEO, L. Estimación de daños potenciales causados por virus involucrados en el "encrespamiento amarillo de la batata". Horticultura Argentina, v. 73, n. 1, p. 55, 2011.

LOZANO, G.; TRENADO, H. P.; VALVERDE, R. A.; NAVAS CASTILLO, J. Novel begomovirus species of recombinant nature in sweet potato (Ipomoea batatas) and Ipomoea indica: taxonomic and phylogenetic implications. Journal of General Virology, v. 90, n. 10, p. 2550-2562, 2009.

MARTINELLI, D. Caracterización biológica y serológica de sweet potato virus G (SPVG) que infecta a cultivos de batata de Argentina: producción de reactivos para su diagnóstico. 2014. Tesis (Licenciatura en Ciencias Biológicas) Universidad Nacional de Córdoba, Córdoba, 2014.

MARTINO, J. A.; DI FEO, L.; RODRIGUEZ PARDINA, P. Primer reporte de sweet potato leaf curl virus en las provincias de Córdoba y Santiago del Estero de Argentina. Revista de la Facultad de Ciencias Exactas, Físicas y Naturales, v. 3, n. 1, p. 105-109, 2016.

MARTINO, J. M.; FONTELE, R. S.; FERREIRA, S. A.; RIBERO, S. G.; DI FEO, L. D. V. First report of sweet potato leaf curl Georgia virus in sweet potato in Argentina. Plant Disease, v. 101, n. 3, p. 513, 2017.

NHLAPO, T. F.; REES, D. J. G.; ODENY, D. A.; MULABISANA, J. M.; REY, M. E. C. Viral metagenomics reveals sweet potato virus diversity in the eastern and western Cape provinces of South Africa. South African Journal of Botany, v. 117, n. 1, p. 256-267, 2018.

PARDINA, P. E.; BEJERMAN, N.; LUQUE, A. V.; DI FEO, L. Complete nucleotide sequence of an Argentinean isolate of sweet potato virus G. Virus Genes, v. 45, n. 3, p. 593-595, 2012.

RODRÍGUEZ PARDINA, P.; LUQUE, A.; NOME, C.; LÓPEZ COLOMBA, E.; FUENTES DELGADO, S.; DI FEO, L. First report of sweet potato leaf curl virus infecting sweet potato in Argentina. Australasian Plant Disease Notes, v. 7, n. 1, p. 157-160, 2012.

SYLLER, J. Facilitative and antagonistic interactions between plant viruses in mixed infections. Molecular Plant Pathology, v. 13, n. 2, p. 204-2016, 2012.

UNTIVEROS, M.; FUENTES, S.; SALAZAR, L. Synergistic interaction between sweet potato chlorotic stunt virus (crinivirus) with Carla-, Cucumo-, Ipomo- and potyviruses infecting sweet potato. Plant Disease, v. 91, n. 6, p. 669-676, 2007. 